\title{
Alternate furrow irrigation can radically improve water productivity of Okra
}

\author{
A. A. Siyal ${ }^{1, *}$, A. S. Mashori ${ }^{2}$, K. L. Bristow ${ }^{3}$ and M. Th. van Genuchten ${ }^{4}$ \\ ${ }^{1}$ U.S.-Pakistan Center for Advanced Studies in Water (USPCAS-W), Mehran University of \\ Engineering and Technology, Jamshoro, Sindh, Pakistan \\ ${ }^{2}$ Department of Farm Power and Machinery, Faculty of Agricultural Engineering, Sindh \\ Agriculture University Tandojam, Pakistan \\ ${ }^{3}$ CSIRO Agriculture, PMB Aitkenvale, Townsville, QLD 4814, Australia and University of \\ Pretoria Water Institute / Department of Plant Production and Soil Science, \\ University of Pretoria, Private Bag X20, Hatfield 0028, South Africa \\ ${ }^{4}$ Department of Mechanical Engineering, Federal University of Rio de Janeiro, UFRJ, Rio de \\ Janeiro, RJ, 21945-970, Brazil
}

*Corresponding author: Telephone +92 3353340405

E-mail addresses: siyal@yahoo.com (Altaf A.Siyal); abdulsattar_03@yahoo.com (Abdul S.

Mashori); Keith.Bristow@csiro.au (Keith L. Bristow); rvangenuchten@hotmail.com

(Martinus. Th. van Genuchten) 


\section{ABSTRACT}

Alternate furrow irrigation (AFI) is gaining interest as a means of saving water while minimising loss in crop production. Given the potential water savings of AFI, a field experiment was conducted in the Tandojam region of Pakistan by growing okra with AFI and conventional furrow irrigation (CFI) in which every furrow is irrigated. Our results show that total irrigation water applied in the AFI treatment was roughly half $(248 \pm 2.9 \mathrm{~mm})$ that applied to the CFI treatment $(497 \pm 1.7 \mathrm{~mm})$. Despite the very significant reduction in irrigation water used with AFI there was a non-significant $(p>0.05)$ reduction $(7.3 \%)$ in okra yield. As a result, we also obtained a significantly $(p<0.001)$ higher crop water productivity (CWP) of $5.29 \pm 0.1 \mathrm{~kg} \mathrm{~m}^{-3}$ with AFI, which was nearly double the $2.78 \pm 0.04 \mathrm{~kg} \mathrm{~m}^{-3}$ obtained with CFI. While this reduction in yield and/or potential income may appear small, it could be critical to the welfare of individual farmers, who may as a result hesitate to make changes from CFI to AFI if they are worse off than farmers who don't adopt AFI. This situation exists because current water charges are based on crop and land area rather than the volume of water being accessed for irrigation. Transitioning from the current crop and land area based method of charging for water to a volumetric method may require investment in irrigation system changes and may take time to accomplish. These are important lessons for other countries, and particularly developing countries who are trying to improve the environmental, social and economic performance of their irrigated systems. We recommend that further studies be carried out using AFI to determine whether similar water savings and flow-on benefits can be achieved across a wide range of cropping systems in arid and semiarid environments.

Keywords: Irrigation efficiency, water use efficiency, water savings, deficit irrigation 


\section{Introduction}

Pakistan's economy is dependent on agricultural production. It is estimated that 70$80 \%$ of the total area cultivated in Pakistan is irrigated through a network of canals. About $93 \%$ of the available fresh water resources are currently utilized in the agricultural sector (Bhangar and Saima, 2008). The increasing population has resulted in demand for more food and fiber, which is met through increasing irrigated agriculture. This translates into increasing pressure on Pakistan's water resources. It is critical therefore that management and utilization of available water resources is improved at all scales; from catchment, to irrigated district, to farm and field scale. Management of water at the macro level is generally expensive, time consuming and difficult. By comparison management of water at the field scale is generally relatively inexpensive, more feasible and practical, and it can be implemented in a short period of time. It is therefore critical to improve water management at the field scale through adoption of more efficient and effective irrigation methods.

About $90 \%$ of the irrigated land of the world is irrigated using relatively inefficient surface irrigation methods (Tiercelin and Vidal, 2006). As a result about 20 to 30 million ha of irrigated lands globally are seriously damaged by the build-up of salts and it is estimated that the area of salt affected soils will increase by about 0.25 to 0.5 million ha per year (FAO, 2002). Similar trends are observed in Pakistan where traditional surface irrigation methods (basin, border and furrow) are widely used to irrigate crops. These are however inefficient methods of irrigation and are considered one of the main causes of waterlogging and salinisation (Ishfaq, 2002). It is because of these sorts of problems that the use of modern, high-tech and efficient micro irrigation methods (drip, bubbler, sprinkler etc.) are advocated worldwide. However, farmers are often reluctant to adopt these high-tech methods, especially in Pakistan and other developing countries, due to their high cost of installation, operation and maintenance. As a result these methods have not yet been widely adopted by 
farming communities in developing countries. There is a need therefore for more efficient irrigation methods that are economical, easy to install and operate, and which are readily acceptable to the farming community.

Furrow irrigation, reported to be one of the least efficient methods compared with other irrigation methods (Burt et al., 1997), is still one of the most widely used forms of surface irrigation. It involves water flow through narrow channels (furrows) spaced regularly across the field (with row spacing often between 1.0 to $2.0 \mathrm{~m}$ ), instead of flooding water over the whole field. Despite its application efficiency remaining relatively low (Ampass and Baltas, 2009), not enough effort is being made to keep improving its management and efficiency. Because furrow irrigation is a well-known, simple and economical method of irrigation, farmers are likely to be ready adopters of new approaches that are practical improvements of their current practices and that result in improved water use efficiency.

It has been suggested (Kang et al., 2000a; Du et al., 2010; Horst et al., 2005) that the efficiency of conventional furrow irrigation (CFI), referred to by some as every furrow irrigation, can be improved by converting it to alternate furrow irrigation (AFI). The AFI method is essentially the same as $\mathrm{CFI}$, except that instead of irrigating every furrow, irrigation is applied to alternate furrows, while the in-between furrows remain dry. This means each ridge receives water from only one side, and the side receiving irrigation water could be changed with each irrigation if the field is set up to facilitate this change. Irrigating just one side of the ridge means there is significant potential to save irrigation water compared to CFI. There is however, also potential in some cases for a reduction in crop yield (Samadi and Sepaskah, 1984; Crabtree et al., 1985; Mashori, 2013). It has been observed that farmers prefer to stick with traditional flood irrigation methods due to their simplicity, ease of operation and maintenance and low installation/construction cost. If the conventional furrow irrigation method (CFI) is transformed into alternate furrow irrigation (AFI) then it might be readily accepted by farmers. However, before introducing and 
advocating this method to local farmers for adoption, the method needs to be evaluated under soil and climatic conditions representative of the areas being targeted for its introduction.

The objective of this study is to report on an experiment in which Okra (Abelmoschus esculentus L.), also known as Lady's finger, was grown using CFI and AFI. Okra is an important vegetable crop grown throughout Pakistan, and the aim of the experiment was to assess the water savings and water productivity improvements that could be achieved with AFI compared with CFI. While we report on benefits of AFI for growing Okra in Pakistan, this paper provides lessons for furrow irrigators in general, and particularly for irrigators in developing countries who don't have access to high tech irrigation methods such as pressurised drip irrigation. 


\section{Materials and Methods}

An experiment with conventional furrow irrigation (CFI) and alternate furrow irrigation (AFI) methods was conducted at a field site with an experimental plot that was $1260 \mathrm{~m}^{2}$ (36.5 m x $34.5 \mathrm{~m}$ ) located in the district Hyderabad, Sindh, Pakistan, at Latitude of $25^{\circ} 25^{\prime} 28^{\prime \prime} \mathrm{N}$ and Longitude of $68^{\circ} 32^{\prime} 26^{\prime \prime} \mathrm{E}$. The elevation at the site is about $26 \mathrm{~m}$ above mean sea level (Figure 1).

The experimental plot was deep ploughed with a moldboard plough and the resulting clods were pulverized with a disc harrow. The whole plot was leveled before demarcation into six subplots, each with a size of $202 \mathrm{~m}^{2}$. The remaining area $\left(48 \mathrm{~m}^{2}\right)$ was used for construction of the water supply canals and bunds between the subplots. The selection of subplots for testing the CFI and AFI methods was completely randomized. Furrows were manually constructed using spades. The furrow to furrow and ridge to ridge distance was $0.8 \mathrm{~m}$. The furrow depth was $0.2 \mathrm{~m}$. The total length of each furrow was $18 \mathrm{~m}$, and there were a total of 14 furrows in each subplot. There were therefore 3 subplots and 42 furrows under each treatment. Subplots were irrigated through a field channel passing through the center of the plot.

Seventy two (72) soil samples were collected from 3 randomly selected locations in each subplot at depths of $0-20,20-40,40-60$ and $60-80 \mathrm{~cm}$ for determining soil texture and soil dry bulk density. Soil texture was determined using the hydrometer method (Bouyoucos, 1962). Soil bulk density was determined using the core method (Grossman and Reinsch, 2002). Soil water contents at saturation (0 bar), field capacity (33.34 $\mathrm{kPa})$ and wilting point $(1500 \mathrm{kPa})$ were also determined using pressure plate apparatus.

Two to three okra seeds were sown at a depth of $4-5 \mathrm{~cm}$ on both sides of the ridge at a rate of $22 \mathrm{~kg} \mathrm{ha}^{-1}$ (MINFAL, 1997) keeping a $0.2 \mathrm{~m}$ plant to plant spacing along the row. The seedlings were inspected once they started to emerge and plants that appeared very 


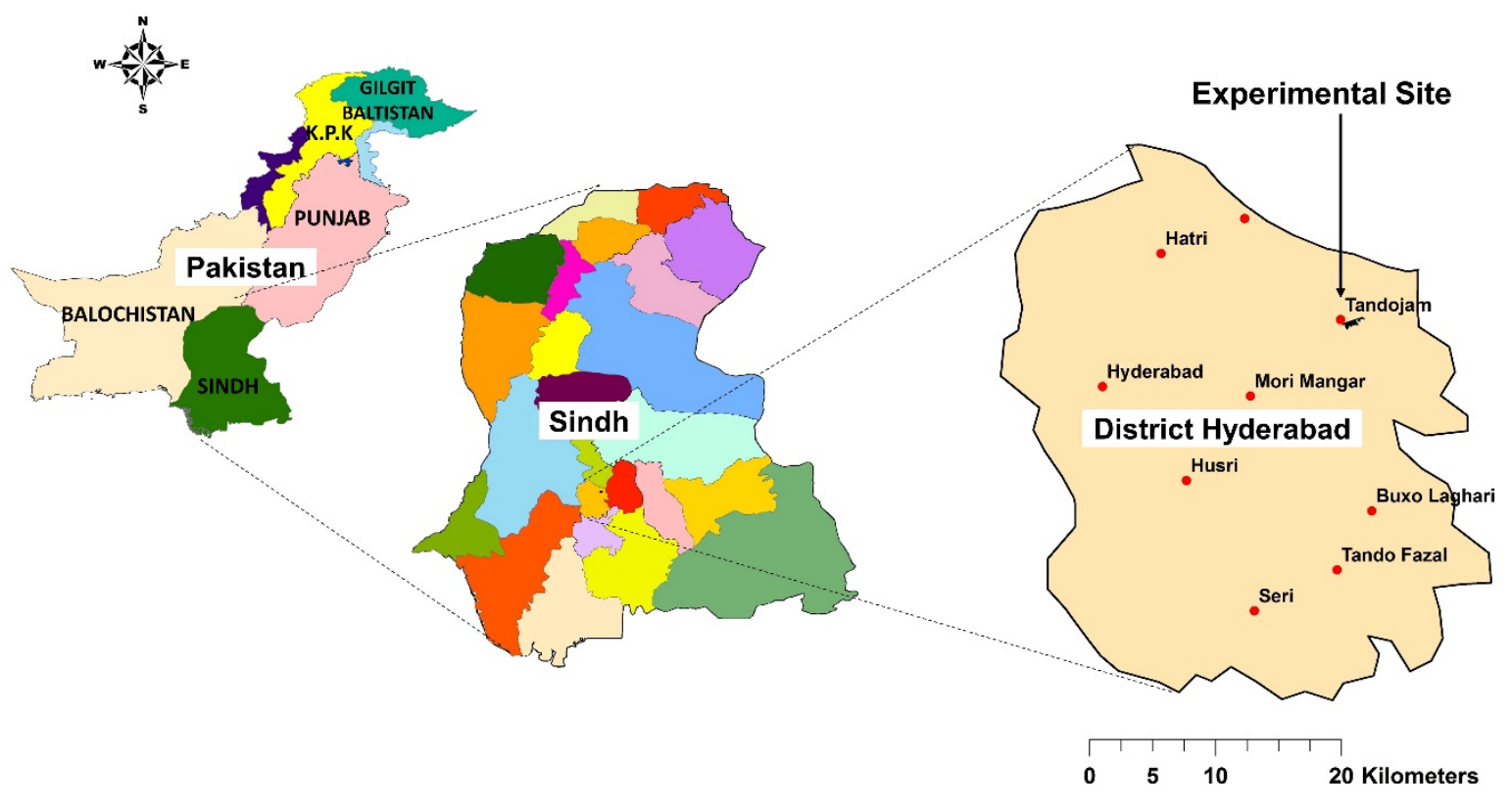

Fig. 1. Schematic showing location of the field experimental site in Pakistan 
weak and unlikely to survive were removed. A total of 2520 plants per treatment (3 subplots) were harvested at maturity. Weeds in all four subplots were removed manually using a hand hoe. Fertilizer was applied to all subplots using recommended quantities (MINFAL, 1997), namely 124 kg Nitrogen ha ${ }^{-1}, 247 \mathrm{~kg}$ Phosphorous ha ${ }^{-1}$ and 124 kg Potassium $\mathrm{ha}^{-1}$.

Meteorological data including air temperature, pan evaporation, daily and total rainfall for the entire growing season was obtained from a nearby weather station.

The total crop water requirement of an okra crop under furrow irrigation is reported to be around $500 \mathrm{~mm}$ per crop growth cycle (MINFAL, 1997). This was split into 8 separate irrigations (62 $\mathrm{mm}$ per irrigation) with an interval of 6 to 8 days between irrigations. Groundwater with an EC of $0.45 \mathrm{dS} \mathrm{m}^{-1}$ was diverted from a nearby tubewell for irrigation. The capacity of the tubewell was 0.5 cusec $\left(14.158 \mathrm{~L} \mathrm{~s}^{-1}\right)$, however during irrigation to furrows, only half of the water flow was diverted while the rest flowed to irrigate the neighboring agricultural land. The irrigation was applied subplot-wise to furrows until the water in the furrows reached the blocked end of the furrows. The water supply was switched off when the water level in the furrows reached $3 / 4$ of the furrow depth. The quantity of water applied to the subplots was measured using cutthroat flume (throat width $=15 \mathrm{~cm}$ ). Before field installation, it was calibrated using a known discharge. The flume was placed on a levelled surface in such a way that free flow occurred. It was aligned straight with the field channel and levelled longitudinally and laterally. The depth of water applied to each subplot was determined using the following relationship:

$$
D=Q . t / A
$$

where $Q$ is discharge $\left(\mathrm{m}^{3} \mathrm{~s}^{-1}\right), t$ is time (sec), $A$ is area of the subplot $\left(\mathrm{m}^{2}\right)$ and $D$ is depth of water $(m)$. 
The crop was sown on June 03, 2013. The first picking of the okra pods (fruit) started 46 days after sowing with the last picking carried out on August 31, 2013. The harvested okra fruit was weighed and recorded.

The water saving with AFI compared to CFI was calculated as:

$$
\text { Water Saving }(\%)=\frac{W_{C}-W_{A}}{W_{C}} \times 100
$$

where $W_{C}$ is total water used $(\mathrm{mm})$ with the CFI method and $W_{A}$ is total water used $(\mathrm{mm})$ with the AFI method.

The okra fruit yield for each subplot was weighed and recorded once the pods had been harvested. The increase/decrease in yield (\%) compared to the AFI method was computed as:

$$
\text { Increase in yield }(\%)=\frac{\left(Y_{A}-Y_{C}\right)}{Y_{A}} \times 100
$$

where $Y_{A}$ and $Y_{C}$ are yields $\left(\mathrm{kg} \mathrm{ha}^{-1}\right)$ obtained with the AFI and CFI methods, respectively.

The crop water productivity (CWP), expressed as $\mathrm{kg} \mathrm{m}^{-3}$ of water, of AFI and CFI was determined using the relationship (Talha and Aziz, 1979):

$$
C W P=\frac{Y}{W_{t}}
$$

where $Y$ is total production of the crop obtained from all 3 subplots under each treatment $\left(\mathrm{kg}\right.$ treatment $\left.\mathrm{t}^{-1}\right)$ and $W_{t}$ is the total water applied $\left(\mathrm{m}^{3}\right.$ treatment $\left.{ }^{-1}\right)$. The total water included both rainfall and irrigation.

The economic analysis comparing CFI and AFI was carried out by accounting for all costs involved in growing, harvesting and selling the Okra crop. The actual costs on a per 
hectare basis for growing Okra in the Tandojam region of Pakistan at the time this study was carried out included tillage, \$150; furrow construction, \$150; Okra seed, \$20; fertilizer and pesticide, \$300; labour for weeding, $\$ 60$; labour for picking pods, $\$ 400$; irrigation water, $\$ 25$; and transportation to market, $\$ 100$. The total cost of $\$ 1205 \mathrm{ha}^{-1}$ for Okra production is the same for both the CFI and AFI treatments. This is because water charges are based on land area and crop grown, and not on the volumetric amount of water accessed for irrigation. The Okra yield determined the amount of product that could be used by the farmer for household consumption or sold at the market. The net return was obtained by deducting the input cost from the value of the total marketable product. 


\section{Results and Discussion}

Table 1 shows the textural class and bulk density of the soil at the experimental field site at four different depths. The profile shows that the soil was medium textured with sand, silt and clay ranging from 23 to $30 \%, 45$ to $52 \%$ and 25 to $27 \%$, respectively. The spatial and depth-wise variation of sand, silt and clay soil fractions was non-significant. The soil bulk density of the profile ranged from $1.32 \mathrm{~g} \mathrm{~cm}^{-3}$ to $1.36 \mathrm{~g} \mathrm{~cm}^{-3}$, with an average value of $1.34 \pm 0.01 \mathrm{~g} \mathrm{~cm}^{-3}$. There were no significant spatial and depth-wise trends in the soil bulk density.

There was $1.5 \mathrm{~mm}$ of rainfall at the field site during the entire crop growth period (June to August). The average monthly temperatures for the months of June, July and August were $39.5^{\circ} \mathrm{C}, 38.2{ }^{\circ} \mathrm{C}$ and $36.8{ }^{\circ} \mathrm{C}$, respectively. The corresponding average daily evaporation rates were $9.11 \mathrm{~mm}, 8.43 \mathrm{~mm}$ and $6.75 \mathrm{~mm}$, respectively.

The total volume of irrigation water applied to each of the AFI subplots was $50.1 \mathrm{~m}^{3}$ (248 mm) while $100.7 \mathrm{~m}^{3}$ (497 mm) was applied to each of the CFI subplots (Table 2). This shows that the subplots under AFI used roughly half the amount of water compared to the subplots under CFI. This decrease in AFI water was a result of irrigating only alternate furrows, which would have also decreased evaporation and deep drainage losses. Our results align with the 46 to $50 \%$ water savings obtained using AFI compared with CFI as reported by Crabtree et al. (1985), Graterol et al. (1989), Khalid et al. (1999), Kang et al. (2000b) and Slatni et al. (2011).

We have also compared our experimental results with data provided by Mashori (2013) who reported that the typical crop water requirement of okra is $720 \mathrm{~mm}$ when grown during the summer season with flood irrigation. Our results show that water savings when irrigating okra with $\mathrm{AFI}$ and $\mathrm{CFI}$ can be as high as $66 \%$ and $31 \%$ compared to flood irrigation. The statistical analysis (ANOVA) of the irrigation water use achieved in our experiment is 
Table 1 Measurements of soil properties at four depths at the field experimental site, including soil texture, soil bulk density and soil water content at saturation (0 $\mathrm{kPa})$, field capacity (33.34 $\mathrm{kPa})$ and wilting point $(1500 \mathrm{kPa})$

\begin{tabular}{|c|c|c|c|c|c|c|c|c|c|}
\hline $\begin{array}{l}\text { S. } \\
\text { No. }\end{array}$ & $\begin{array}{l}\text { Soil depth } \\
\text { (cm) }\end{array}$ & $\begin{array}{c}\text { Sand } \\
\%\end{array}$ & $\begin{array}{l}\text { Silt } \\
\%\end{array}$ & $\begin{array}{l}\text { Clay } \\
\%\end{array}$ & $\begin{array}{c}\text { Textural } \\
\text { class }\end{array}$ & $\begin{array}{l}\text { Dry bulk } \\
\text { density } \\
\left(\mathrm{g} \mathrm{cm}^{-3}\right)\end{array}$ & $\begin{array}{l}\text { Saturation } \\
\text { Capacity } \\
\left(\mathrm{cm}^{3} \mathrm{~cm}^{-3}\right)\end{array}$ & $\begin{array}{l}\text { Field } \\
\text { Capacity } \\
\left(\mathrm{cm}^{3} \mathrm{~cm}^{-3}\right)\end{array}$ & $\begin{array}{l}\text { Wilting point } \\
\left(\mathrm{cm}^{3} \mathrm{~cm}^{-3}\right)\end{array}$ \\
\hline 1 & $0-20$ & $23 \pm 0.31$ & $52 \pm 0.47$ & $25 \pm 0.62$ & Silt Loam & $1.32 \pm 0.08$ & $0.41 \pm 0.03$ & $0.33 \pm 0.02$ & $0.16 \pm 0.02$ \\
\hline 2 & $20-40$ & $30 \pm 0.62$ & $46 \pm 0.60$ & $24 \pm 1.02$ & Loam & $1.36 \pm 0.07$ & $0.38 \pm 0.04$ & $0.30 \pm 0.04$ & $0.14 \pm 0.02$ \\
\hline 3 & $40-60$ & $26 \pm 0.46$ & $48 \pm 0.43$ & $26 \pm 0.57$ & Loam & $1.33 \pm 0.04$ & $0.39 \pm 0.03$ & $0.31 \pm 0.04$ & $0.16 \pm 0.03$ \\
\hline 4 & $60-80$ & $28 \pm 0.34$ & $45 \pm 0.47$ & $27 \pm 0.69$ & Loam & $1.33 \pm 0.02$ & $0.40 \pm 0.02$ & $0.33 \pm 0.03$ & $0.15 \pm 0.02$ \\
\hline
\end{tabular}

\pm Denotes confidence interval 
Table 2 A comparison of irrigation water used in alternate furrow irrigation (AFI), conventional furrow irrigation (CFI) and flood irrigation under three different irrigation methods irrigation methods and water savings with CFI and AFI methods

\begin{tabular}{|c|c|c|c|c|c|}
\hline \multirow[t]{2}{*}{ Irrigation methods } & \multicolumn{3}{|c|}{ Irrigation water used } & \multicolumn{2}{|c|}{ AFI water savings (\%) } \\
\hline & $\mathrm{m}^{3}$ subplot $^{-1}$ & $m^{3} h a^{-1}$ & $\mathrm{~mm}$ & $\begin{array}{l}\text { Compared } \\
\text { with flood } \\
\text { irrigation }\end{array}$ & $\begin{array}{c}\text { Compared } \\
\text { with CFI }\end{array}$ \\
\hline AFI & $50.1 \pm 0.36$ & $2480 \pm 18$ & $248 \pm 2$ & 66 & 50 \\
\hline CFI & $100.4 \pm 0.21$ & $4970 \pm 10$ & $497 \pm 1$ & - & - \\
\hline Flood irrigation* & - & 7200 & 720 & - & - \\
\hline
\end{tabular}

*Literature values taken from Mashori (2013)

\pm Denotes confidence interval 
presented in Table 3(a). It shows that the difference in irrigation water use between the CFI and AFI methods for growing okra was highly significant $(p<0.001)$.

The total okra crop yield obtained with AFI and CFI is given in Table 4. It shows that the okra yield under AFI was $265 \mathrm{~kg}$ subplot ${ }^{-1}$, which is equivalent to $13,118 \mathrm{~kg} \mathrm{ha}^{-1}$. Similarly, total okra crop yield under CFI was $286 \mathrm{~kg}$ subplot $^{-1}$, equivalent to $14158 \mathrm{~kg} \mathrm{ha}^{-1}$. Okra yield in Pakistan using flood irrigation has been reported as $9,900 \mathrm{~kg} \mathrm{ha}^{-1}$ (Rahman et al. 2012). Yield obtained with AFI and CFI in our experiment was roughly $33 \%$ and $43 \%$ higher than that obtained by Rahman et al. (2012) with flood irrigation. When compared to CFI, the yield obtained with AFI was about 7\% less. The statistical analysis (ANOVA) of the okra crop yield obtained in our experiment is presented in Table 3(b). It shows that the difference in okra crop yield obtained with CFI and AFI was non-significant $(p>0.05)$. A slight reduction in crop yield with AFI compared to CFI was also reported by Majeedano (2012), Bakker et al. (1995), Sepaskhah and Ghasemi (2008), and Rafiee and Shakarami (2010). Crabtree et al. (1985) also found a yield reduction in sorghum and soybeans when using AFI. This is also supported by Stone and Nofziger (1993) who found that AFI may result in lower yields because too little water is applied, particularly when evaporative rates are very high.

Under the AFI method, the okra plant root system was partially wetted which could result in reduced stomatal conductance and a reduction in plant transpiration. Photosynthesis and dry matter accumulation can however be less affected by this partial stomatal closure (Kang et al., 2000a). Also, the roots on the irrigated side of the furrow (wet soil) will continue to take up water to try and meet the required water demand of the plant (Ahmadi et al., 2010). Zhang et al. (1987) reported that plants with two halves of their root system under alternate drying and wetting cycles resulted in reduced stomatal opening but without significant increase in leaf water deficit. This could be part of the reason why there was a non-significant reduction in crop yield with AFI compared with CFI. Kang et al. (2000a) also observed a high grain yield for corn when subjected to a $50 \%$ reduction in the amount 
Table 3 (a): ANOVA of irrigation water used by CFI and AFI methods

\begin{tabular}{lccccc}
\hline Source of Variation & df & SS & MS & $\mathbf{F}_{\text {cal }}$ & $\mathbf{F}_{\text {tab@0.1\% }}$ \\
\hline Between groups & 1 & 3795.1 & 3795.1 & 14596.7 & 74.1 \\
With groups & 4 & 1.04 & 0.26 & & \\
Total & 5 & 3796.1 & & & \\
\hline
\end{tabular}

Table 3 (b): $\quad$ ANOVA of the crop yield obtained with CFI and AFI methods

\begin{tabular}{lccccc}
\hline Source of Variation & df & SS & MS & $\mathbf{F}_{\text {cal }}$ & $\mathbf{F}_{\text {tab@5\% }}$ \\
\hline Between groups & 1 & 661.5 & 661.5 & 5.75 & 7.70 \\
With groups & 4 & 460.0 & 115.0 & & \\
Total & 5 & 1121.5 & & & \\
\hline
\end{tabular}

Table 3 (c): $\quad$ ANOVA of the crop water productivity of CFI and AFI methods

\begin{tabular}{lccccc}
\hline Source of Variation & $\mathbf{d f}$ & $\mathbf{S S}$ & $\mathbf{M S}$ & $\mathbf{F}_{\text {cal }}$ & $\mathbf{F}_{\text {tab@0.1\% }}$ \\
\hline Between groups & 1 & 8.9 & 8.9 & 445.6 & 74.1 \\
With groups & 4 & 0.80 & 0.20 & & \\
Total & 5 & 9.01 & & & \\
\hline
\end{tabular}


Table 4 Okra yield and percentage increase/decrease in yield with AFI compared with CFI and flood irrigation methods

\begin{tabular}{|c|c|c|c|c|}
\hline \multirow{2}{*}{ Irrigation method } & \multicolumn{2}{|c|}{ Crop yield } & \multicolumn{2}{c|}{ Yield increase/decrease } \\
\cline { 2 - 5 } & Per sub-plot & Per hectare & Compared to Flood & Compared to CFI \\
& & & irrigation method & method \\
\hline AFI & $265 \pm 6.80$ & $13118 \pm 337$ & 33 & -7 \\
\hline CFI & $286 \pm 5.50$ & $14158 \pm 272$ & 43 & -- \\
\hline Flood & --- & $9900 *$ & -- & - \\
\hline
\end{tabular}

*Literature values taken from Rahman et al. (2012) 
of irrigation applied. Panigrahi et al. (2011) reported alternate partial root-zone irrigation as a productive and potential water saving technique for okra cultivation in sandy loam soils. Sepaskhah and Ahmadi (2010) also recommended partial root zone drying (similar to AFI) for better fruit quality and increased crop water productivity in areas with limited water resources.

Table 5 shows the crop water productivity (CWP) of AFI, CFI and flood irrigation methods for growing okra. The highest CWP of $5.29 \mathrm{~kg} \mathrm{~m}^{-3}$ was obtained with AFI followed by CFI with $2.78 \mathrm{~kg} \mathrm{~m}^{-3}$ and then flood irrigation, which had the lowest CWP. The statistical analysis (ANOVA) of CWP is given in Table 3(c). It shows that the variation in CWP for both treatments was highly significant $(p<0.001)$, which highlights the effect the method of irrigation has on CWP. Ibrahim et al. (2010) reported that the AFI method had higher CWP compared with the CFI method. Stone et al. (1982) and Slatni et al. (2011) reported that AFI resulted in a slight decrease in crop yield but an increased water productivity. Rafiee and Shakarami (2010) also reported that AFI enables more efficient use of irrigation water but with a lower crop yield associated with some water stress compared to CFI.

Table 6 provides a summary of the economic analysis of CFI and AFI. It shows that the input cost per hectare for growing okra using CFI and AFI is the same $(\$ 1205 / h a)$, because water charges are based on the crop grown and the area of crop that is irrigated and not on the volume of water accessed for irrigation. The per hectare crop production for AFI and CFI is however different because of the different amounts of water available to the crop, with the net return being $\$ 4458$ for CFI and $\$ 4042$ for AFI. This shows that the farmer who accessed roughly $50 \%$ less water using AFI than the farmer who used $\mathrm{CFI}$, will have about $1040 \mathrm{~kg} \mathrm{ha}^{-1}$ (or $7 \%$ ) less edible product if they keep it to use, or will be $\$ 416$ dollars (or $9 \%$ ) worse off if they sell their total crop. While $7 \%$ less yield or $9 \%$ less income may not seem like much to some people, it could be critical to the welfare of individual farmers who might not have access to other off farm resources. And they will certainly question why they 
Table 5 Crop water productivity, defined as kg of yield per cubic meter of water applied, obtained with alternate furrow irrigation (AFI), conventional furrow irrigation (CFI) and flood irrigation

\begin{tabular}{|c|c|}
\hline Irrigation Method & Crop water productivity $\left(\mathrm{kg} \mathrm{m}^{-3}\right)$ \\
\hline AFI & $5.29 \pm 0.10$ \\
\hline CFI & $2.78 \pm 0.04$ \\
\hline Flood & $1.37^{*}$ \\
\hline
\end{tabular}

${ }^{*}$ Calculated from literature data with crop water requirement $=7200 \mathrm{~m}^{3} \mathrm{ha}^{-1}$ (Mashori, 2013) and crop yield $=9900 \mathrm{~kg} \mathrm{ha}^{-1}$ (Rahman et al., 2012) 
Table 6 Economic analysis demonstrating the difference in benefits obtained between the CFI and AFI treatments. The production costs are the same for both the CFI and AFI treatments because water charges are based on land area and crop grown, and not on the volumetric amount of water accessed for irrigation.

\begin{tabular}{|c|c|c|}
\hline & CFI & AFI \\
\hline Total cost of Okra production (\$ ha $\left.{ }^{-1}\right)$ & 1205 & 1205 \\
\hline Cost of water $\left(\$ \mathrm{ha}^{-1}\right)$ & 25 & 25 \\
\hline Water applied $\left(\mathrm{m}^{3} \mathrm{ha}^{-1}\right)$ & $4970 \pm 10$ & $2480 \pm 18$ \\
\hline Okra production (kg ha-1) & 14,158 & 13,118 \\
\hline Crop water productivity $\left(\mathrm{kg} \mathrm{m}^{-3}\right.$ ) & $2.84 \pm 0.1$ & $5.29 \pm 0.1$ \\
\hline Okra selling price $\left(\$ \mathrm{~kg}^{-1}\right)$ & 0.40 & 0.40 \\
\hline Total return $\left(\$ \mathrm{ha}^{-1}\right)$ & 5663 & 5247 \\
\hline Net return $\left(\$ h^{-1}\right)$ & 4458 & 4042 \\
\hline
\end{tabular}


should change if they see a decrease in yield or income for adopting improved water use efficiency practices compared with those who retain their much less efficient irrigation practices.

Pakistan is a water stressed country and the Government is urging farmers to improve their water use efficiency by adopting more efficient irrigation practices. Based on the results of this study this will be difficult to achieve when famers who adopt new more efficient irrigation practices like AFI that save large amounts of water, are worse off than farmers who continue using CFI and don't invest in improving their irrigation water use efficiency.

Given that AFI can reduce water use by as much as $50 \%$ compared with $\mathrm{CFI}$, widespread adoption of AFI has the potential to produce massive public benefits as the water saved by using AFI could be used to improve environmental flows and/or to expand irrigation downstream. Encouraging adoption of water use efficient irrigation practices like AFI will, however, require changes to the way farmers pay for irrigation water. The best way to achieve this is to move from crop and land area based water charges to volumetric based water charges (Nyberg and Rozelle, 1999). Paying for each litre of water accessed for irrigation will serve as a real incentive for farmers to adopt the most efficient irrigation practices possible, and moving from CFI to AFI is not a difficult or costly thing to do. Making the change requires instead a mind shift so that water and irrigation management decisions deliver the benefits that AFI is capable of.

Easter and Liu (2005) demonstrated that introduction of volumetric pricing in the Yangtze Basin Water Resource Project in China reduced irrigation costs as farmers used less water per hectare. Losses associated with delivery of water also decreased. It is clear that the volumetric method of charging for water is effective, but transitioning from the current crop and land area based method to a volumetric method may require investment in irrigation system changes and may take some time to accomplish (Hassan and Chaudhry, 
1998). These are important lessons for other countries, and particularly developing countries, who are trying to improve the environmental, social and economic performance of their irrigated systems. 


\section{Conclusions and Recommendations}

Results of our field study on alternate furrow irrigation (AFI) for okra production demonstrates that this method can (i) deliver water savings in excess of $50 \%$ compared with conventional furrow irrigation (CFI), (ii) radically improve okra water productivity, and (iii) be used as a practical management tool to save water so that it can be put to other uses. These other uses could include improved groundwater levels, improved environmental flows and hence improved river and estuary health and/or to expand irrigation downstream. Potential economic implications to individual farmers may however result in hesitation to make changes from CFI to AFI if they are worse off from a yield and/or financial point of view than farmers who don't adopt AFI. This situation exists because current water charges are based on crop and land area rather than the volume of water being accessed for irrigation. Transitioning from the current crop and land area based method to a volumetric method may require government investment in irrigation system changes and may take time to accomplish. We recommend that further studies be carried out using AFI to determine whether similar water savings and flow on benefits can be achieved across a wide range of cropping systems in arid and semi-arid environments. 


\section{References:}

Ahmadi, S.H., Andersen, M.N., Plauborg, F., Poulsen, R.T., Jensen, C.R., Sepaskhah, A.R., Hansen, S. 2010. Effects of irrigation strategies and soils on field grown potatoes: Gas exchange and xylem [ABA]. Agri. Water Management, 97: 1486-1494.

Ampas, V. and E. Baltas., 2009. Optimization of the furrow irrigation efficiency. Global NEST Journal 11(4), 566-574

Bakker, D.M., Raine, S.R. and Robertson, M.J., 1995. A preliminary investigation of alternate furrow irrigation for sugar cane production. Conference Proc. 'Clean water-clean Environment-21st Century, March 1995, Kansas City, Missouri, ASAE.

Bhangar, M. I. and Saima, Q. M., 2008. Water research activities in Pakistan. Proceedings of the 1st Technical Meeting of Muslim Water Researchers Cooperation (MUWAREC) December. p. 82

Bouyoucos, J.B., 1962. Hydrometer method for making particle-size analysis of soil. Agronomy Journal 54, 464-465.

Burt, C.M., Clemmens, A.J., Strelkoff, T.S., Solomon, K.H., Bliesner, R.D., Hardy, L.A., Howell, T.A., Eisenhauer, D. E., 1997. Irrigation performance measures: Efficiency and uniformity. Journal of Irrigation and Drainage Engineering 123: 423-442.

Crabtree, R.J., Yassin, A.A., Kargougou, I., Mc New, R.W., 1985. Effect of alternate furrow irrigation: water conservation on the yields of two soybean cultivars. Agricultural Water Management 10(3), 253-264.

Du, T. S., Kang, S. Z., Sun, J. S., Zhang, X. Y. and Zhang, J. H., 2010. An improved water use efficiency of cereals under temporal and spatial deficit irrigation in north China. Agricultural Water Management 97(1), 66-74.

Easter, W. and Liu, Yang. 2005. Cost Recovery and Water Pricing for Irrigation and Drainage Projects. The World Bank. Agriculture and Rural Development Discussion Paper 26 
FAO, 2002. Crops and Drops: Making the Best Use of Water for Agriculture. Food and Agriculture Organization of The United Nations, Rome.

Graterol, T.E., Einsenhaver D.E., Elmore, R.W., 1989. Alternate furrow irrigation for soybean production. Agricultural Water Management 24, 133-145.

Grossman R.B., Reinsch, T.G., 2002. Methods of Soil Analysis Ch2, ed. Dane J.H, Clarke Topp G. Soil Science Society of America, Inc. Madison, Wisconsin, USA.

Hassan, M.U., and Chaudhry, M.G. 1998. Assessing Water Charges under Changing Institutional Irrigation Management in Pakistan: A Methodological Framework. The Pakistan Development Review, 37(1): 1-17

Horst, M. G., Shamutalov, S. S., Pereira, L. S., Goncalves, J. M., 2005. Field assessment of the water saving potential with furrow irrigation in Fergana, Aral Sea basin. Agricultural Water Management 77(1-3), 210-231.

Ibrahim, M.A.M., Emara, T.K., 2010. Water saving under alternative furrows surface Irrigation in clay soils of north Nile delta. Fourteen International Water Technology Conference pp 811-821.

Ishfaq, A., 2002. Water new technology. Global Change Impact Studies Centre (GCISC), Islamabad, Pakistan.

Kang, S. Z., Liang, Z. S., Pan, Y. H., Shi, P. Z., and Zhang, J. H., 2000a. Alternate furrow irrigation for maize production in an arid area. Agricultural Water Management 45, 267-274.

Kang, S.Z., Shi, P., Pan, Y.H., Liang, Z.S. Hu, X.T., Zhang, J., 2000b. Soil water distribution, uniformity and water-use efficiency under alternate furrow irrigation in arid areas. Irrigation Science 19(4), 181-190

Khalid H. K., Rana, M. A., Arshad, M., 1999. Alternate furrow irrigation for enhancing water use efficiency in cotton. Pakistan Journal of Agricultural Science 36(3-4), 175-177 
Majeedano, I., 2012. Agro Digest. Agronomy Section, Agriculture Research Institute, Tandojam, Sindh, Pakistan. p.43.

Mashori, A. S., 2013. Evaluation of the performance of the alternate furrow irrigation under climatic conditions of Sindh. M. E. Thesis, Sindh Agriculture University, Tandojam, Pakistan.

MINFAL, 1997. Irrigation Agronomy. On Farm Water Management Field Manual. Government of Pakistan. VI. p 175.

Nyberg, A. and Rozelle, S. 1999. Accelerating the China's rural transformation. The World Bank. p 73

Panigrahi, P., Sahu, N.N. and Pradhan, S. 2011. Evaluating partial root-zone irrigation and mulching in okra (Abelmoschus esculentus L.) under a sub-humid tropical climate. Journal of Agriculture and Rural Development in the Tropics and Subtropics, 112(2): $169-175$

Rahman, K., Waseem, K., Kashif, M., Jilani, M.S., Kiran, M., Ghazanfar, U., Mamoon, R., 2012. Performance of different okra (abelmoschus esculentus I.) cultivars under the agroclimatic conditions of Dera Ismail Khan. Pakistan Journal of Science 64(4), 316-319.

Rafiee, M., Shakarami, G., 2010. Water Use Efficiency of Corn as Affected by Every Other Furrow Irrigation and Planting Density. World Applied Sciences Journal 11 (7), 826829.

Samadi, A., Sepaskah, A.R., 1984. Effects of alternate furrow irrigation on yield and water use efficiency of dry beans. Iran Agricultural Research 3(2), 95-115.

Sepaskhah, A. R. and Ahmadi, S.H. 2010. A review on partial root-zone drying irrigation. International Journal of Plant Production, 4 (4): 241-258

Sepaskhah, A.R. and Ghasemi, M., 2008. Every other furrow irrigation with different intervals for sorghum. Pakistan Journal of Biological Sciences 11(9), 1234-1239. 
Slatni, A., Zayani, K., Zairi, A., Yacoubi, S., Salvador R., Playan, E., 2011. Assessing alternate furrow strategies for potato at the Cherfech irrigation district of Tunisia. Journal Biosystems Engineering 108(2), 154-163.

Stone, J.F., Nofziger, D.L., 1993. Water use and yields of cotton grown under wide-spaced furrow irrigation. Agricultural Water Management 24(1), 27-38.

Stone, J.F., Reeves, H.E., Garton, J.E., 1982. Irrigation water conservation by using widespaced furrows. Agricultural Water Management 5, 309-317.

Talha, M., Aziz, M. A. 1979. Effect of irrigation and fertilization on yield and water economy of potato plant. Egypt J. of Soil Sci., 19 (2), 231-243.

Tiercelin, J.R., Vidal, A., 2006. Traite' d'Irrigation, 2nd ed. Lavoisier, Technique and Documentation, Paris, France.

Zhang, J., Schurr, U. and Davies, W.J. 1987. Control of stomatal behaviour by abscisic acid which apparently originates in roots. J. Exp. Bot. 38: 1174-1181. 